J Epidemiol Community Health 2007;61(Suppl II):iil-ii2.

doi: 10.1136/jech.2007.069658

\section{Authors' affiliations}

Ana M García, Mel Bartley, Carlos Alvarez-

Dardet, Journal of Epidemiology and

Community Health

Ana M García, Department of Preventive Medicine and Public Health, University of Valencia, and Trade Union Institute for Work, Environment and Health, Valencia, Spain Mel Bartley, Department of Epidemiology and Public Health, University College of London, London, UK

Carlos Alvarez-Dardet, Department of Public Health, University of Alicante, Spain

\section{Correspondence to: Ana M García, Instituto} Sindical de Trabajo, Ambiente y Salud, Almirante 3, puerta 4, 46003 Valencia, Spain; anagar@uv.es

\section{REFERENCES}

1 Krieger N. Genders, sexes, and health: what are the connections and why does it matter? Int J Epidemiol 2003;32:652-7.

2 Lawlor DA. What's in a name? J Epidemiol Community Health 2004;58:726.

3 García AM, Alvarez-Dardet C. A journal for evidence based policies. J Epidemiol Community Health 2005;59:716-7.

4 Leigh JP, Fries JF, Hubert HB. Gender and race differences in the correlation between body mass and education in the 1971-1975 NHANES I. J Epidemiol Community Health 1992;46:191-6.

5 Berntsson L, Lundberg U, Krantz G. Gender differences in work-home interplay and symptom perception among Swedish white-collar employees. $J$ Epidemiol Community Health 2006;60:1070-6.

6 Mansdotter A, Lindholm L, Lundberg M, et al. Parental share in public and domestic spheres: a population study on gender equality, death, and sickness. J Epidemiol Community Health 2006;60:616-20.

7 Kavanagh AM, Bentley R, Turrell G, et al. Does gender modify associations between self rated health and the social and economic characteristics of local environments? J Epidemiol Community Health 2006:60:490-5

8 Ratner PA, Tzianetas R, Tu AW, et al. Myocardial infarction symptom recognition by the lay public: the role of gender and ethnicity. J Epidemiol Community Health 2006:60:606-15.

9 Colomer-Revuelta C, Peiró-Pérez R, LópezRodríguez RM, et al. Policies, politics and gender research. J Epidemiol Community Health 2007:61(Suppl II):ii2

10 Colomer C, Peiró R. Techos de cristal y escaleras resbaladizas? Desigualdades de género y estrategias de cambio en SESPAS. [Glass ceiling and slippery stairs? Gender inequalities and strategies for change in the Spanish Society of Public Health and Health Services Administration] Gac Sanit 2002;16:358-60.

11 Peiró R, Ramón N, Alvárez-Dardet C, et al. Sensibilidad de género en la formulación de planes de salud en España: lo que pudo ser y no fue. [Gender Sensitivity in the Formulation of Spanish health plans: what if could have been but wasn't] Gac Sanit 2004;18(Suppl II):36-46.

12 Llácer A, Zunzunegui MV, del Amo J, et al. The contribution of a gender perspective to the understanding of migrants' health. J Epidemiol Community Health 2007:61(Suppl II):ii4-10.

13 Ruiz-Cantero MT, Ronda E, Álvarez-Dardet C. The importance of study design strategies in gender bias research: the case of respiratory disease management in primary care. J Epidemiol Community Health 2007;61(Suppl II):ii1 1-16.

14 Ruiz MT, Verbrugge LM. A two way view of gender bias in medicine. J Epidemiol Community Health 1997;51:106-9

15 Peiró-Pérez R, Colomer-Revuelta C, BlázquezHerranz M, et al. Applications submitted and grants awarded to men and women in nationwide biomedical competitive research, in 2006, in Spain. J Epidemiol Community Health 2007;61(Suppl II):ii 17-19.

16 López-Carrillo M. Doctor Aleu, the first woman doctor in Spain. J Epidemiol Community Health 2007;61(Suppl II):ii3.

17 López-Carrillo M. Aphorism of the month. J Epidemiol Community Health 2007;61(Suppl II):ii25.

18 Valls-Llobet C. Estrogen's storm season. Stories of perimenopause. J Epidemiol Community Health, 2007:61(Suppl II):ii54.

19 Rohlfs I, Borrell C, Artazcoz L, et al. The incorporation of gender perspective into Spanish health surveys. J Epidemiol Community Health 2007:61(Suppl II):iii20-5.

20 Ruiz-Pérez I, Plazaola-Castaño J, Vives-Cases C. Methodological issues in the study of violence against women. J Epidemiol Community Health 2007:61(Suppl II):ii26-31.

21 García-Calvente M del Mar, Castaño-López E, Mateo-Rodríguez I, et al. A tool to analyse gender mainstreaming and care-giving models in support plans for informal care: case studies in Andalusia and the United Kingdom. J Epidemiol Community Health 2007:61(Suppl II):ii32-8.

22 Artazcoz L, Borrell C, Cortès I, et al. Occupational epidemiology and work related inequalities in health: a gender perspective for two complementary approaches to work and health research. J Epidemiol Community Health 2007;61(Suppl II):ii39-45.

23 Ruiz-Cantero MT, Vives-Cases C, Artazcoz L, et al. A framework to analyse gender biases in epidemiological research. J Epidemiol Community Health 2007;61(Suppl II):ii46-53.

\title{
Policies, politics and gender research
}

\section{Concha Colomer-Revuelta, Rosana Peiró-Pérez, Rosa M López- Rodríguez, Isabel Espiga-López, Isabel Sáiz-Martínez-Acitores, Isabel Soriano-Villarroel}

\section{Development of research on gender and health is scarce}

$\mathrm{T}$ oday, the importance of adopting a gender approach is widely acknowledged when it comes to planning and assessing policies, programmes and health services. But it is also obvious, on the other hand, that development of research on gender and health, and on women's health, that allows taking action to be based on scientific knowledge, is rather scarce.

More and more frequently research results are presented, either broken down by sex, or sex is included as a variable for study and analysis. We know that this is still insufficient for understanding health inequalities arising from gender, and for taking steps to reduce them. Gender issues are giving rise to growing interest, but their study has been kept away from medicine, for which the concern has chiefly been biology ( sex and not gender), and where the broadly adopted model has been male disease. On close inspection, it may be seen that, broadly speaking, resources devoted to health and gender research in Spain have been, up until recently, rather scarce, both in terms of personnel and funding and, hence, yielded poor results ${ }^{1}$ and limited application to policies. ${ }^{2}$ Present development stems from the initiative, back at the end of the 1990s, of creating a task force within the Spanish Society of Public Health and Healthcare Administration (SESPAS). ${ }^{3}$ This task force developed an observatory, debating forums at symposiums, and the inclusion of gender inequalities in SESPAS reports. ${ }^{45}$
In 2002, within the framework of convening research networks, at the "Carlos III" Health Institute-the Spanish agency for biomedical research-the Research Network for Health and Gender (RISG) ${ }^{6}$ was created. Throughout recent years the RISG has helped to promote this kind of research, conducting and spreading studies and training female researchers. This supplement is intended to promote international dissemination of a part of that work carried out to contribute to the general knowledge of these subjects and to be shared by interested people and organisations in other countries.

Research on gender and health in Spain has been strengthened since 2005 by its priority line funding in national research grant proposal convening. This comes as a result of a Spanish government equality policy that establishes specific measures for action, targeting achievement of equality objectives in all sectors. ${ }^{7}$ In the case of the Ministry of Health and Consumer Affairs, this translated into the creation of the Observatory on Women's Health dependent on the National Health System's Quality Agency and into the inclusion of gender equity in the Quality Plan for the National Health System. ${ }^{8}$

Political support at the highest level also allows other actions that are relevant for 
research purposes, such as revision of information services, in health and within the healthcare system, to achieve whatever information be broken down by sex, and the inclusion of variables enabling research on gender inequalities. ${ }^{90}$ Also this support helps in the process of devising and financing the research, ranging from improving the quality of the applications, and designing of studies on gender and health, to gender awareness in application assessment processes. At all stages, shortcomings have been detected that have set in motion actions such as training and methodological support to emerging health and gender research teams. In this sense, the Observatory on Women's Health is working to develop a series of guidelines for gender mainstreaming in the different stages of research. The first, about research policies, is already available. ${ }^{11}$

Publication of research results, specifically in scientific journals, is basic for knowledge dissemination. It has been shown than gender stereotypes have some impact in this field by hindering women's works. ${ }^{12}$

These actions are expected to come to completion in the oncoming years, thus contributing to a deepened understanding of the magnitude and causes of gender inequalities in Spain, as well as in the whole scientific world, and hence providing knowledge for the kind of political action that may enable ongoing progress towards these inequalities reduction, to thrive on.

$J$ Epidemiol Community Health 2007;61(Suppl II):ii2-ii3.

doi: 10.1136/jech.2007.066225

\section{Authors' affiliations}

Concha Colomer-Revuelta, Rosana Peiró-Pérez, Rosa M López-Rodríguez, Isabel Espiga-López, Isabel Sáiz-Martínez-Acitores, Isabel SorianoVillarroel, Observatory on Women's Health, NHS's Quality Agency's Directorate General, Ministry of Health and Consumers' Affairs, Madrid, Spain

Rosana Peiró-Pérez, CIBER Epidemiologia y Salud Pública (CIBERESP), Spain

Correspondence to: Concha Colomer-Revuelta, Observatorio Salud de la Mujer y del Sistema Nacional de Salud, DG Agencia de Calidad de SNS, Ministerio de Sanidad y Consumo, Paseo del Prado 18-20, 28071 Madrid, Spain; ccolomer@msc.es

\section{REFERENCES}

1 Castaño-López E, Plazaola-Castaño J, BolívarMuñoz J, et al. Publicaciones sobre mujeres, salud y género en España (1990-2005). (Publications on women, health and gender in Spain (1990-2005.) Rev Esp Salud Pública 2006:80:705-16.

2 Peiró R, Ramón N, Álvarez-Dardet C, et al. Sensibilidad de género en la formulación de planes de salud en España: Lo que pudo ser y no fue. (Gender sensitivity in the formulation of Spanish health plans: what it could have been but wasn't.) Gac Sanit 2004;18(suppl 2):36-46.

3 Género. sespas.es [página en internet]. Barcelona: Grupo de Género y Salud Pública. Sociedad Española de Salud Pública y Administración Sanitaria (SESPAS). (Gender and Public Health Group. Spanish Society of Public Health and Health Services Administration) [homepage on the internet], Feb 2000 [updated 1 May 2007; accessed 26 May 2007] Available from: http:// genero.sespas.es/.

4 Borrell C, García-Calvente MdM, Martí-Boscà JV, eds. La salud pública desde la perspectiva de género y clase social [Monografía en internet] Barcelona: Informe SESPAS 2004. (Public health from gender and social class perspective [monograph on the internet]. [Accessed 26 May 2007] Available from: http://www.sespas.es/ fr inf.html.
5 Colomer-Revuelta, C, Peiró-Pérez R. ¿̇Techos de cristal y escaleras resbaladizas? Desigualdades de género y estrategias de cambio en SESPAS. [Glass ceiling and slippery stairs? Gender inequalities and strategies for change in the Spanish Society of Public Health and Health Services Administration.) Gac Sanit 2002;14:358-60.

6 redgenero. web.esp. [página en internet]. Granada: Red de Investigación en Salud y Género (RISG). (Gender and health research network) [homepage on the internet] [Accessed 26 May 2007] Available from: http://www.easp.es/ redgenero/web/esp/index.asp.

7 Constitutional Act 3/2007 of 22 March for effective equality between women and men. [Accessed 26 May 2007] Available from: http://www.mtas.es/ igualdad/legislacíon/EqualityAct3-2007pdf.

8 Equidad. Salud y género. [página en internet]. Madrid: Plan de Calidad para el Sistema Nacional de Salud. Ministerio de Sanidad y Consumo. (Equity, health and gender. [Homepage on the internet] Madrid: Quality Plan for the Nacional Health System. Ministry of Health and Consumer Affairs.) [Accessed 26 May 2007] Available from: http://www.msc.es/organizacion/sns/ planCalidadSNS/e02 htm.

9 Rohlfs I, Borrell C, Anitua C, et al. La importancia de la perspectiva de género en las encuestas de salud. (The importance of gender perspective in health surveys.) Gac Sanit 2000;14:146-55.

10 García-Gómez M, Castañeda-López R. Enfermedades profesionales declaradas en hombres y mujeres en España en 2004. (Professional diseases declared in men and women in Spain in 2004.) Rev Esp Salud Pública 2006:80:349-60.

11 García-Calvente MdM, Jiménez-Rodrigo ML, Martínez-Morante E. Políticas de investigación en salud. Guía de recomendaciones para la incorporación de la perspectiva de género, (Research policies in health.Guide of recommendations for the incorporation of the gender perspectiva [monograph on the internet]). Madrid: Observatorio de salud de la Mujer, Ministerio de Sanidad y Consumo, 2006. [Accessed 26 May 2007] Available from:http:// www.msc.es/organizacion/sns/ planCalidadSNS/pdf/equidad/ PROPUESTA_DE_GUIA_NIVEL_POLITICAS DE_INVESTIGACION_EN_SALUD.pdf

12 Lawlor D. What's in a name? J Epidemiol Community Health 2004;58:726.

\section{GALLERY}

\section{Doctor Aleu, the first woman doctor in Spain}

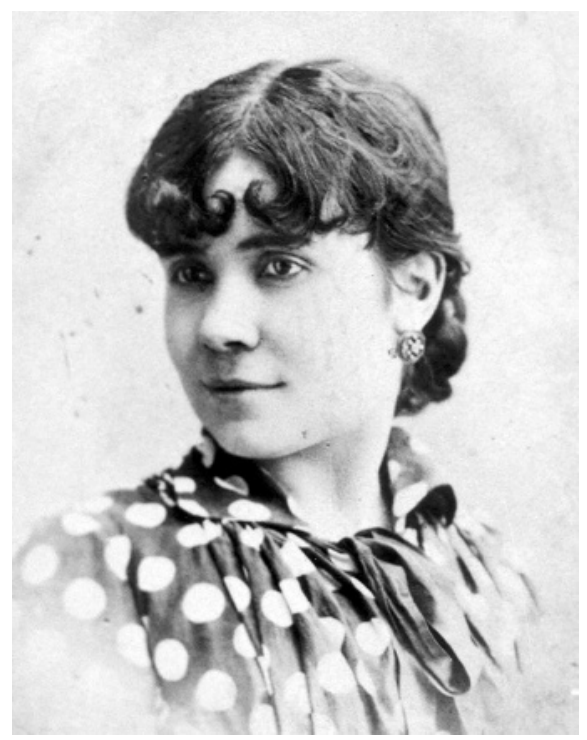

D octor Dolors Aleu (Barcelona, 1857-1913) was the first woman to study medicine in Spain She completed her university education in 1879 but was not granted permission to take the graduation exam until 1882, when she also obtained her doctorate. She fought single handedly to achieve a medical degree, moved by the conviction that denying access to it was an act of social injustice towards women. "Despite there being so many social concerns, we are denied instruction, and the poor women who actually make the superhuman effort of reaching the fountains of science are constantly ridiculed..."

In her doctoral thesis, entitled "On the need to set the hygienic and moral education of women on a new course," she harshly criticised discrimination against women in all realms of life, the social hypocrisy that bans women from education, arguing that they are weak and have to bear the burden of families, while neither is taken into account when it comes to putting them to work like dogs on farms or in factories, as well as the unhealthiness of female attire, particularly corsets.

Dr Aleu married and had two children, but this did not prevent her from practising medicine until her death at the age of 56.

Correspondence to: Dr Margarita López-Carrillo, CAPS, París, 150 1r 2a Barcelona 08036, Spain; redcaps@pangea.org

Doctor Dolors Aleu 